\title{
Die gestremde as werknemer: Werkgewerperspektief
}

\author{
René Uys en N.P. du Preez \\ Nagraadse Skool vir Bestuurswese, P.U. vir C.H.O., Potchefstroom, 2520 Republiek van Suid-Afrika
}

Aanvaar 19 Mei 1988

\begin{abstract}
An extensive research project with a response rate of $35 \%$ was undertaken under various companies in South Africa. The purpose of the project was to determine the attitude of employers in the open labour market towards disableds as employees. The researchers also wanted to determine the extend whereto disableds are employed within the labour market, as well as what their application and work successes are. In addition the research will focus on the various disabilities, and persons' abilities, training and expectations. The viewpoint of the research project is that today in the era of self-determination handicapped people do not want to be hired because they are handicapped. Nor do they want to be denied a job because of their handicap. Rather, they want to be treated as any other person. They want an equal chance to demonstrate their abilities and to live up to their potential. They want equal access to education, training and employment. They want to prove that they are people who can do the work and they want others to stop thinking about their handicapping condition.
\end{abstract}

\begin{abstract}
'n Omvangryke navorsingsprojek, waarop die responskoers $35 \%$ was, is in samewerking met ondernemings in Suid-Afrika gedoen. Die doel was om te bepaal wat die gesindheid van die werkgewer in die ope-arbeidsmark teenoor die gestremde as werknemer is. Die navorsers wou ook bepaal tot watter mate gestremdes in die opearbeidsmark in diens geneem word, die mate van hulle aanwending en wat hul werkprestasies is. Daar word gepoog om te bepaal wat die onderskeie gestremdhede en persone se vermoëns, vaardighede, opleiding en bepaalde verwagtinge is. Die uitgangspunt van die navorsingsprojek is dat die gestremde in vandag se 'gelykegeleenthede-omgewing' nie in diens geneem wil word omdat hulle gestremd is nie, maar hulle wil ook nie 'n pos geweier word as gevolg van hul gestremdheid nie. Hulle wil eerder op dieselfde wyse as alle ander werknemers hanteer word. Hulle wil gelyke geleenthede hê om hulle vermoëns en vaardighede uit te leef en om hulle potensiaal ten volle te benut. Hulle wil gelyke geleenthede tot opvoeding, opleiding en indiensname hê. Hulle wil bewys dat hulle wel die werk kan doen en hulle wil hê dat ander moet ophou konsentreer op hul gestremdheid en dit wat hulle nie kan doen nie.
\end{abstract}

\section{Aard en omvang van navorsing}

\section{Probleemstelling}

Die verwagtinge en nuwe benadering van die gestremde persoon soos gestel in die opsomming het verrykende implikasies, nie slegs vir die gestremde persoon nie, maar ook vir onder meer opleidingsinstansies en werkgewers. Ten spyte daarvan dat die gestremdes klaarblyklik geestelik gereed is vir groter uitdagings, gelyke geleenthede en toetrede tot die ope-arbeidsmark, is die omgewing (sosiaal), opleiding en werkgewers nie noodwendig gereed, voorberei of toeganklik vir die gestremde persoon nie.

Dit is dus belangrik om in die eerste plek deur middel van navorsing te bepaal hoe die huidige situasie daar uitsien, veral ten opsigte van die ope-arbeidsmark. Belangrik is ook om vas te stel tot watter mate die gestremde in diens geneem word, hoe hy binne hierdie werksituasie presteer en wat die ervaring van die werkgewer in die ope-arbeidsmark in hierdie verband is.

\section{Doelwitte van artikel}

Hierdie artikel dek slegs een faset van die totale navorsingsprojek, naamlik die gestremdes en die perspektief van werkgewers in die ope-arbeidsmark. Alhoewel die navorsingsprojek tydens die jaar van gestremde persone ' $n$ aanvang geneem het, is die doel nie slegs om in hierdie enger verband ' $n$ bydrae te lewer nie, maar ook tot die breër mannekragsituasie.

Hierdie studie sal waarskynlik ook die belangrike rol wat die gestremde as potensiële werknemer in die verligting van die opgeleide mannekragtekort in SuidAfrika kan speel, aandui.

Volgende fases van die projek (en artikels) sal konsentreer op die gestremde persoonlik asook versorgings- en opleidingsinstansies vir gestremdes, assosiasies en rade vir gestremdes asook beskutte en beskermde arbeidsinstansies. Kruiskorrelasie sal dus na voltooiing van die totale projek kan plaasvind om 'n geheelbeeld te skep.

Daar sal in hierdie artikel gefokus word op onder andere:

- die mate waartoe gestremdes in die ope-arbeidsmark in diens geneem word;

- die gesindheid van werkgewers in die opearbeidsmark teenoor die gestremde werknemer;

- die werkprestasie van die gestremde werknemer in die ope-arbeidsmark met klem op produktiwiteit, sosiale aanpasbaarheid en al die ander faktore wat voorgehou word as redes waarom gestremdes nie in diens geneem word nie;

- ondernemings wat nie tans gestremde werknemers in diens het nie, die redes daarvoor en of hierdie ondernemings voorheen gestremdus in diens gehad het. Indien wel word daar ook aandag aan hierdie ondervinding gegee.

\section{Navorsingsmetodiek en navorsingsomvang}

'n Vraelys wat spesifiek op die werkgewer in die opearbeidsmark gerig is, is ontwikkel. Die vraelys dek die volle spektrum van werkgewers wat tans gestremdes in diens het, wat voorheen gestremdes in diens gehad het 
asook die wat nog nooit gestremdes in diens gehad het nie.

Hierdie vraelys is onder dekbrief aan 2400 ondernemings versend. Die steekproef is uit die volgende saamgestel:

- Alle ondernemings met werknemers wat as volle lede van die instituut vir personeelbestuur geregistreer is;

- alle ondernemings wat op die Johannesburgse Effektebeurs genoteer is;

- alle landboukoöperasies;

- 'n $10 \%$ ewekansige steekproef van munisipaliteite, met 'n aanvullende doelbewuste seleksie van die grootste munisipaliteite;

- 'n $10 \%$ ewekansige steekproef van geregistreerde kleinsakeondernemings;

- alle staatsdepartemente;

- alle staats- of semi-staatsinstellings;

- alle tersiêre opleidingsinstansies;

- alle ondernemings wat op die adreslys van die PU vir $\mathrm{CHO}$ geregistreer is; en

- 'n telefoongids steekproef.

Teen die finale sperdatum is ' $n$ responskoers van $35 \%$ terugontvang. Aanvullend hiertoe is onderhoude met 30 toonaangewende werkgewers gevoer, waartydens bykomende aspekte wat uit die navorsing belangrik blyk te wees, gedek is.

Die inligting is statisties verwerk en ontleed. Die bevindings en aanbevelings oor die werkgewer as party binne die konteks van die gestremde as werknemer word in hierdie artikel weergegee.

\section{Bovindings ten opsigte van ondernemings wat gestremdes in diens het}

Van die ondernemings wat as inligtingsbron tot hierdie artikel oor gestremdes gedien het, het $45,1 \%$ aangedui dat hulle wel gestremdes in diens het. Daarteenoor het $54,8 \%$ geen gestremde werknemers in diens nie. Oppervlakkig beskou lyk die verhouding redelik, maar verdere ontleding toon aan dat slegs 3032 gestremde persone uit ' $n$ totaal van 1171081 werknemers by hierdie ondernemings in diens is.

Gestremde werknemers vorm dus $0,258 \%$ van die totale aantal werknemers wat in diens is. Dit beteken dat slegs een gestremde werknemer vir elke 386 niegestremde werknemers in diens is, vergeleke met 11 gestremdes vir elke 100 nie-gestremde persone in die samelewing. (Bevinding: Jaar van gestremde persone, 1986).

Die verpligte indiensname van gestremdes in Amerika (VSA) en Engeland (VK) is $2 \%$. (Rowland, Pers. med., 1986). Die Nasionale Raad vir Blindes en Instituut vir Dowes en Blindes is van oordeel dat verpligte indiensname van $4 \%$ in Suid-Afrika ingestel behoort te word. Gemeet aan die bevindings wat later in hierdie artikel weergegee sal word oor die produktiwiteit, afwesigheid en sosiale aanvaarding van die gestremde werknemer kan die vraag tereg gevra word of verpligte indiensname nie 'n oplossing is nie, veral siende dat vrywillige indiensname so laag is.

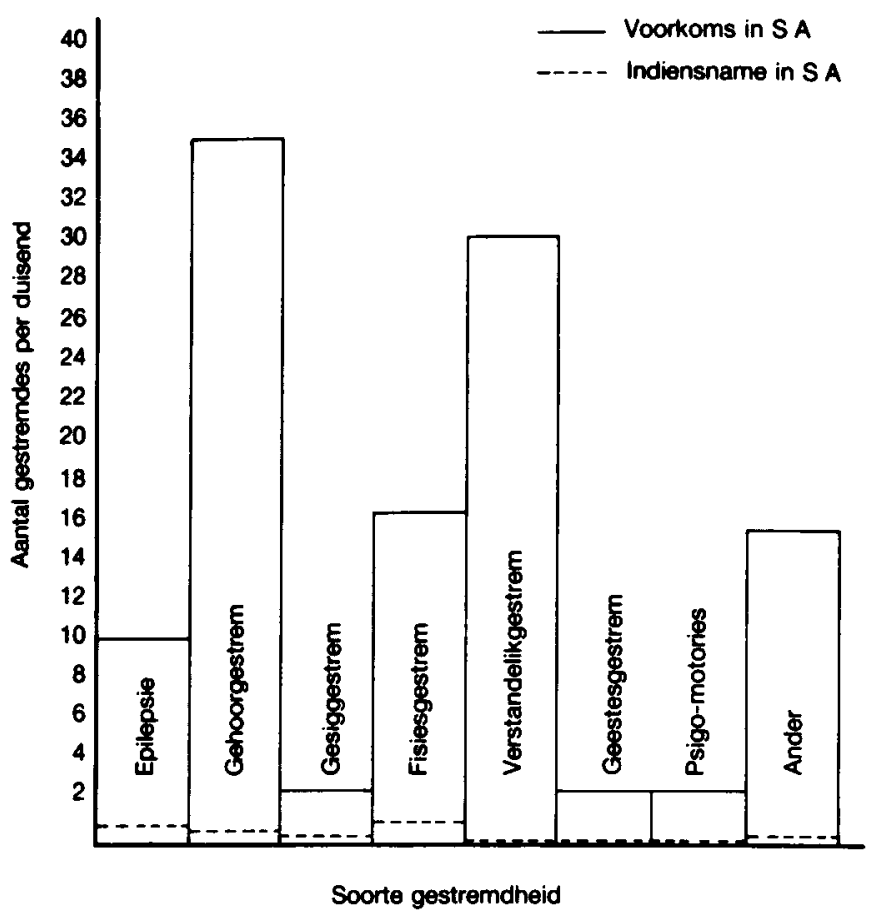

Figuur 1 Verspreiding van gestremdes volgens tipe gestremdheid (aantal per duisend volgens tipe gestremdheid)

Uit die ontleding van die gegewens soos verstrek deur die respondente (verwys Figuur 1), blyk dit dat werkgewers voorkeur verleen aan die indiensname van fisiese gestremdes, byvoorbeeld persone met amputasies of parapleë eerder as persone met funksionele gebreke soos byvoorbeeld sielkundige afwykings of blinde persone.

Die hoër indiensname van fisiese gestremdes kan klaarblyklik daaraan toegeskryf word dat werkgewers meen dat persone met fisiese gebreke se optrede meer voorspelbaar en daarom meer betroubaar is. Die grafiek bevestig ook die algemene stelling dat daar veral teen dié gestremdhede gediskrimineer word wat nie onmiddellik sigbaar is nie, byvoorbeeld epilepsie en gehoorgestremdheid. (English in Florian, 1979: 38). Uit die grafiek blyk dan ook dat hierdie groepe in laer persentasies as byvoorbeeld gesiggestremdes in diens geneem word, alhoewel dit in verhouding groter getalle beteken.

Tydens die plasing van 'n gestremde in 'n bepaalde pos of tydens die identifisering van poste wat deur gestremdes (mits hulle oor die regte kwalifikasies en vaardighede beskik) gevul sal kan word, is dit belangrik om die volgende in gedagte te hou:

- Daar moet weg beweeg word van die stereotipe beroepe vir gestremdes, byvoorbeeld telefonie vir blindes. Die gemeenskap kan sodoende baat omdat die gestremde 'n produktiewe lid van die samelewing word in plaas daarvan om ' $n$ las te wees. Terselfdertyd baat die gestremde omdat hy 'n positiewe selfbeeld ontwikkel (Esterhuizen \& Van der Burgh, 1982: 7).

- Die werkgewer se benadering tydens indiensplasing moet verander. Die werkgewer moet nie probeer om 'n gestremde te plaas nie, maar om vir die vakature 'n gekwalifiseerde persoon te werf - wat moontlik 
gestremd mag wees. Dit beteken nie dat die realiteit van die gestremdheid en die beperkings wat dit inhou geïgnoreer moet word nie. Te dikwels val die klem egter op die gestremdheid.

- Die werkgewer moet in gedagte hou dat die indiensneming van gestremde en nie-gestremde werknemers nie van mekaar verskil nie. Soos wat niegestremde persone 'n wye spektrum vaardighede en vermoëns het, beskik die gestremde ook oor dieselfde spektrum vaardighede en vermoëns. (Nesbitt \& Hippolitus, 1977: 37).

Op die vraag aan ondernemings wat reeds gestremdes in diens het, waarom hulle bereid was om gestremdes in diens te neem het $86,98 \%$ van die ondernemings aangedui dat die gestremde persoon óf geskik was vir die pos of die beste aansoeker was. Slegs $15,88 \%$ het aangetoon dat hulle gestremdes om humanitêre redes in diens neem, terwyl die ander redes waaruit die respondente kon kies 'n minimale rol gespeel het.

Voorgenoemde terugvoer skakel in by die benadering van die gestremdes persoonlik, (Nesbitt \& Hippolitus, 1977: 56), naamlik dat hulle nie in diens geneem wil word omdat hulle gestremd is nie, maar omdat hulle 'n gelyke geleentheid wil hê om hulle vermoëns en vaardighede te benut.

Wanneer werkgewers, wat nie gestremdes in diens het nie, gevra word waarom hulle nie gestremdes in diens neem nie, skuil hulle agter verskonings soos dat hulle te veel aanpassings binne die werksomgewing sal moet maak, of lae produktiwiteit, hoë afwesigheid- en ongelukssyfers, of dat die gestremdes nie deur medewerknemers aanvaar sal word nie. Dat hierdie houding op wanopvatting en onkunde gegrond is, kan uit die volgende bewys word:

- Eerstens uit die bestaande literatuur oor navorsing wat reeds in hierdie verband gedoen is. Florian (1978:

38) stel byvoorbeeld dat daar in professionele literatuur aangedui word dat suksesvolle rehabilitasie dikwels bereik word wanneer die gestremde persoon as werknemer in die ope-arbeidsmark aanvaar word.

- Gade \& Toutges (1983: 353) gaan verder en stel dat, van alle vorme van diskriminasie teen die volwasse gestremde persoon, oortref niks die diskriminasie wat ten opsigte van indiensname voorkom nie. Hulle sê egter dat die veiligheidsrekord, aanwesigheid en produktiwiteitsyfers van gestremdes volgens uitgereikte verslae goed is en selfs beter is as die van ander werkers.

Die navorsing waaroor hier gerapporteer word, het bogenoemde bevindings ook onomwonde bewys en bevestig.

Van al die ondernemings wat reeds gestremdes in diens het, het slegs $30,4 \%$ angedui dat hulle vir hul gestremde werknemers bykomende voorsiening moes maak. Die voorsiening wat gemaak moes word sluit onder andere die volgende in: die toelaat van 'n gidshond op die terrein, ' $n$ braille tikmasjien, aanpassing ten opsigte van die ablusiegeriewe, 'n meganiese hystoestel vir 'n rolstoel en hulp met die lees van omsendbriewe en memorandi.

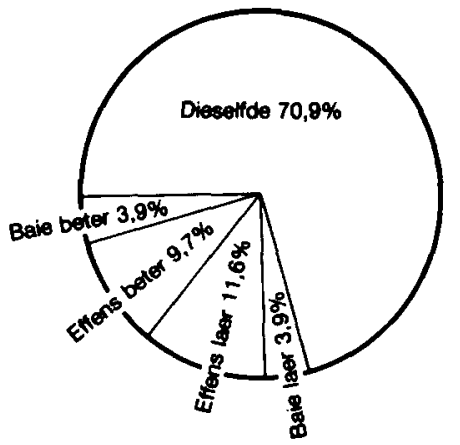

Figuur $2 a$ Produktiwiteit van gestremdes relatief tot ander werknemers

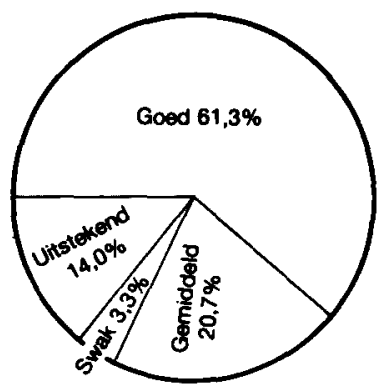

Figuur 2b Sosiale aanpasbaarheid van gestremdes

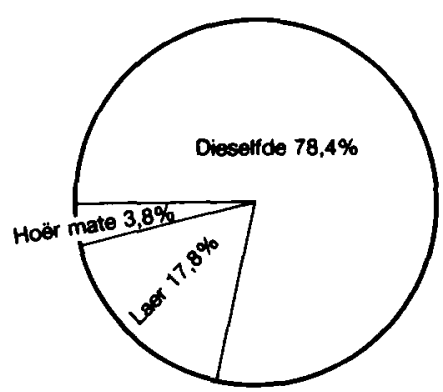

Figuur 2c Geneigdheid tot afwesigheid onder gestremdes

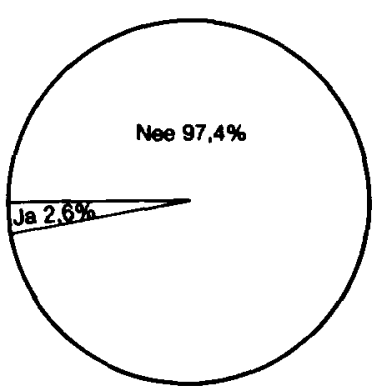

Figuur 2d Voorkoms van werkbeserings onder gestremdes

Strukturele veranderinge wat aan geboue gemaak moet word na die voltooiing van 'n gebou, is waarskynlik die duurste vorm van voorsiening wat gemaak kan word. In die geheel beskou behoort spesiale voorsiening dus geen faktor by die beoordeling van die geskiktheid van 'n gestremde werknemer vir 'n bepaalde pos te wees nie.

Met betrekking tot die produktiwiteit van gestremde werknemers is ongeveer $85 \%$ van die ondernemings wat gestremdes in diens het van mening dat die gestremde 
werknemer net so produktief of selfs produktiewer as die nie-gestremde werknemer is. Die gestremde werknemer se sosiale aanpasbaarheid oortref oor die algemeen dié van die nie-gestremde terwyl hul afwesigheidsyfer of laer of dieselfde is. Indien daar dan verder in ag geneem word dat daar nie 'n hoër, maar eerder 'n laer voorkoms van werkbeserings onder die gestremde werknemers is, is dit duidelik dat die geloof in die teenoorgestelde ' $n$ mite is. Verwys ook in hierdie verband na Figure $2 a-d$.

Uit voorgaande figure blyk dit dat slegs $3,9 \%$ van gestremde werknemers minder produktief as ander werknemers is, slegs $3,3 \%$ is swakker sosiaal aanpasbaar as ander werknemers, $3,8 \%$ het 'n hoër geneigdheid tot afwesigheid as ander werknemers en die voorkoms van werkbeserings kom slegs by $2,6 \%$ van die gestremde werknemers voor.

Ten opsigte van produktiwiteit, sosiale aanpasbaarheid, geneigdheid tot afwesigheid en werkbeserings behoort die gestremde werknemer, indien korrek aangewend/benut, dieselfde of beter diens aan die werkgewer te lewer as sy nie-gestremde kollega.

Aanvullend tot die voorgenoemde vier 'mites', voer die werkgewers dikwels ook aan dat hulle nie gestremdes in diens kan neem nie omdat die ander werknemers hulle nie sal aanvaar nie.

Die navorsing het aangetoon dat die aanvaarding deur bogeskiktes feitlik $90 \%$ en deur gelykes asook deur ondergeskiktes ongeveer $80 \%$ is. Daarteenoor is daar minder as $2 \%$ van voorgenoemde groepe wat die gestremde in die werksituasie negatief beskou. Vergelyk in hierdie verband Figuur 3.

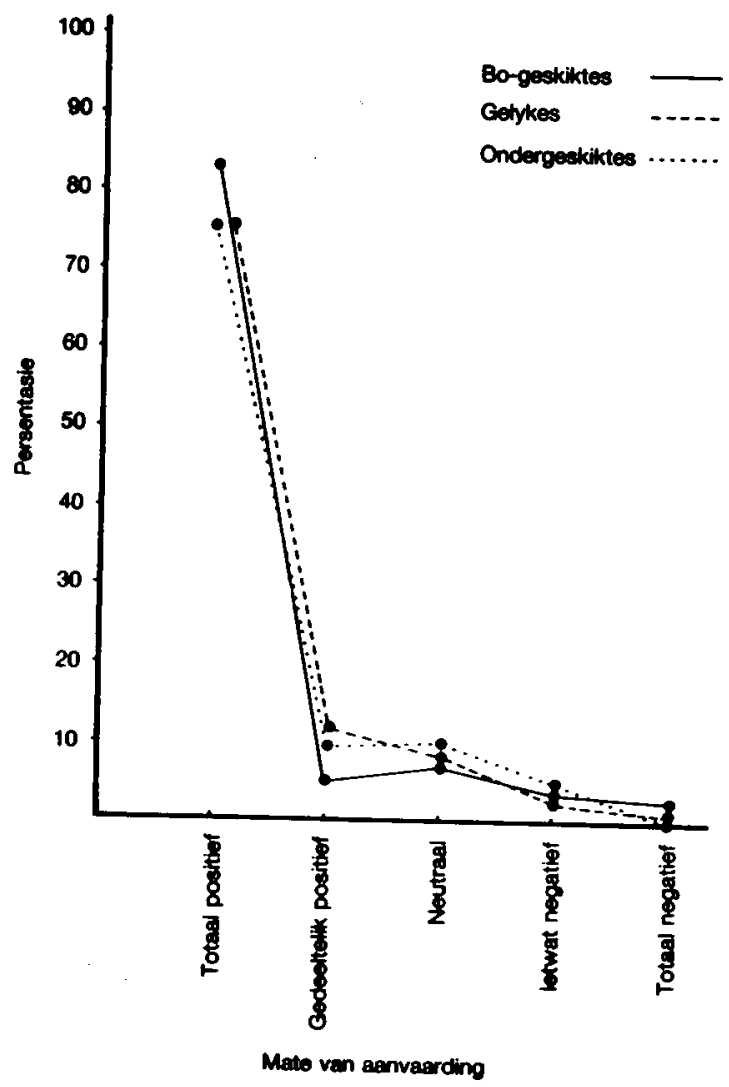

Figur 3 Aanvaarding van die gestremde werknemer deur ander werknemers
Die hoë mate van aanvaarding wat uit die figuur spreek, word saamgevat deur Sears (1975: 21) wanneer hy sê dat 'present employees will be proud of their company for giving disabled veterans and other handicapped people the opportunity to become one of them'.

Voorgenoemde is waarskynlik die grondslag vir die feit dat $77 \%$ van die ondernemings wat reeds gestremdes in diens het, aangedui het dat hulle weer gestremde persone in diens sal neem, terwyl $23 \%$ aangedui het dat hulle nie weer gestremdes in diens sal neem nie. Die voorkeurverdeling deur werkgewers ten opsigte van verdere indiensname van gestremdes stem baie ooreen met die huidige patroon van indiensname. Werkgewers verkies om weer die tipe gestremdheid waarmee hulle reeds bekend is in diens te neem. Geen onderneming het egter kon aandui dat hulle oor 'n beleid ten opsigte van die indiensname van gestremdes beskik nie.

Ondanks die positiewe beeld wat reeds van die gestremde geskep is, is die werklikheid van geleenthede wat aan die gestremde gegee word, nie so positief nie. Sowat $35 \%$ van die gestremde werknemers het nie dieselfde vorderingsgeleenthede tot nie-bestuursvlak- of bestuursvlakposte as ander werknemers nie. Gemiddeld $10 \%$ het geen vorderingsgeleentheid nie. Die gestremdes het ook aangedui dat, hoewel ondernemingsbeleid gelyke geleenthede voorsien, dit nie in die praktyk toegepas word nie.

Die meeste ondernemings het ook aangedui dat salarisse en byvoordele vir gestremde en nie-gestremde persone dieselfde is. 'n Ander ondersoek het egter aangedui dat hierdie gelyke salarisse en byvoordele net bestaan vir persone wat permanente poste beklee. Die gestremde vind dit egter moeilik om 'n permanente pos te bekom en word dikwels tydelik aangestel. Deur so 'n tydelike aanstelling word die verantwoordelikhede, maar ook die risiko (aldus die werkgewer) van die onderneming verlaag (Cilliers, Pers. med., 1986).

\section{Ondernemings wat nie gestremdes in diens het nie}

Dat gestremdes in so ' $n$ geringe mate in die opearbeidsmark in diens geneem word, is egter nie uitsluitlik aan die gesindheid van die werkgewer toe te skryf nie. 'n Afdeling van die vraelys is afgestaan aan dié ondernemings wat die vraelys ontvang het, maar nie gestremdes in diens het nie.

Die ondernemings wat geen gestremdes in diens het nie, is versoek om prioriteitsgewys die redes daarvoor aan te dui. Uit die terugvoer blyk dit dat dit hoofsaaklik is omdat hulle geen aansoeke van gestremdes ontvang het nie, of dat die aard van die werk nie vir gestremdes geskik is nie, of dat hulle nie weet waarvoor om gestremdes aan te wend nie.

Die feit dat die meeste ondernemings aangedui het dat hulle nog geen aansoeke van gestremdes ontvang het nie, óf nie weet hoe om die gestremde aan te wend nie, plaas 'n groot vraagteken agter die 'bemarking' van gestremdes as potensiële werknemers aan werkgewers. Indien 'n werkgewer nie gekonfronteer word met die moontlikheid van 'n gestremde as werknemer nie. of 
indien ' $n$ gestremde nie bereid is of die geleentheid kry om tydens keuring op gelyke voet met 'n ander potensiële werknemer te kompeteer nie, sal sodanige werknemer nie in diens geneem (kan) word nie.

Dit is belangrik dat die gestremde in die regte pos vir sy bepaalde vermoëns geplaas word omdat 'n verkeerde plasing, 'n enkele mislukking, die deure sluit vir dié wat wou volg - en geleenthede is skaars!

Die plasing van die gestremde in die ope-arbeidsmark is, wanneer dit deur opgeleide personeel hanteer word, 'n wetenskap. Deeglike evaluering en beoordeling van die bepaalde individu, wat soms oor maande strek en talle werksituasies dek, word deur 'n span kenners soos sielkundiges, arbeidsterapeute en maatskaplike werkers asook die plasingsbeampte van die betrokke Nasionale Raad uitgevoer. ' $n$ Deeglike ontleding word ook van poste en die werksituasie waarbinne dit uitgevoer word, gedoen. Eers daarna word die twee elemente bymekaar gebring.

Alle parameters soos fisieke vermoëns, houdings en intellek, die posvereistes en die fisieke omstandighede van die potensiële werkgewer word oorweeg in die proses van plasing.

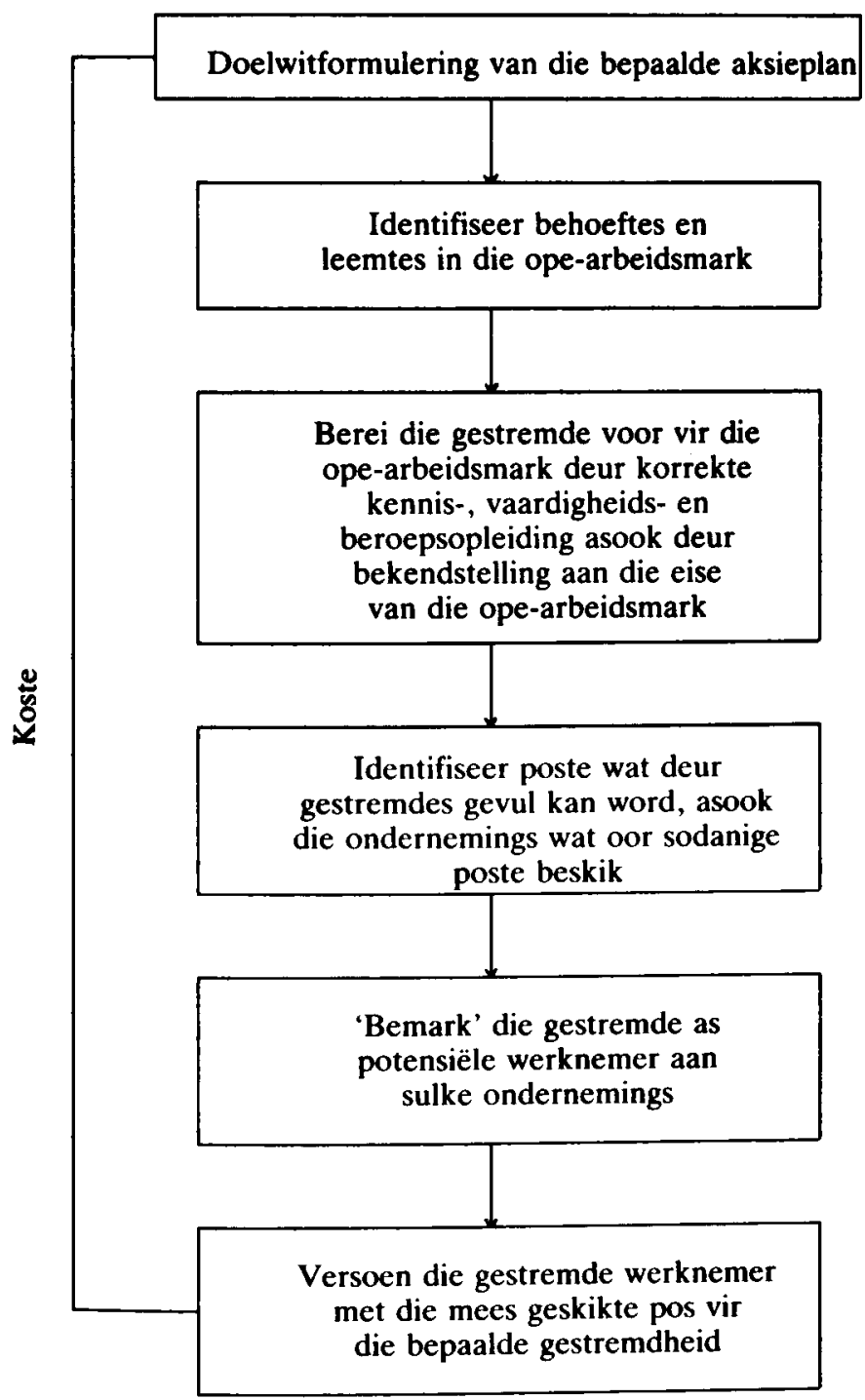

Figuur 4 Vloeidiagram van 'n aksieplan vir die bevordering van die gestremde as werknemer
As plasing so wetenskaplik gedoen word, en met die inagneming van voorgenoemde positiewe aspekte van die gestremde as werknemer, behoort die indiensneming van gestremdes vir die werkgewer asook die gestremde werknemer 'n positiewe ervaring te wees.

\section{Aanbovelings}

Daar bestaan ' $n$ behoefte aan 'n nasionale bewusmaking van die gestremde as werknemer. Werkgewers moet ingelig word aangaande hul produktiwiteit, potensiaal, sosiale aanvaarding, die afwesigheid en vaardighede. Die klem moet hier dus val op die feit dat gestremde werknemers (soos blyk uit die navorsing) ten opsigte van hierdie aspekte dieselfde of beter as nie-gestremde werknemers presteer. Hierdie bekendstelling/bemarking van gestremdes behoort op 'n kontinue basis gedoen te word deur media-dekking en simposia vir werkgewers en gesaghebbende publikasies. Kundiges op die terrein soos navorsers oor die onderwerp, gestremdes en werkgewers wat reeds positief ingestel is kan vir hierdie doel aangewend word. Inligting vir bemarking kan uit onder andere navorsingsverslae bekom word.

Voorgenoemde bemarkingsveldtog moet egter nie net gedurende 'n nasionale jaar vir gestremde persone tot 'n piek gedryf word en daarna laat vaar word nie, maar moet 'n kontinue aksie wees. Belangriker nog, daar moet ten opsigte van sodanige bemarking nuwe visie en kreatiwiteit aan die dag gelê word.

In die stimulering van die indiensname van gestremde persone kan aansporings aan die werkgewer vanaf owerheidsweë ' $n$ belangrike rol speel. Daar bestaan tans wel aansporingsmaatreëls in die vorm van 'n subsidie wat oor 'n periode van drie jaar aan 'n onderneming, wat 'n gestremde persoon in diens neem, uitbetaal word. Die doel met hierdie subsidie is hoofsaaklik om te kompenseer vir 'n produktiwiteitsverlies wat gedurende hierdie periode mag voorkom.

Aansporings behoort egter op tweërlei gebiede aandag te geniet. Eerstens is dit belangrik dat daar bepaal word wat die geskiktheid/toepaslikheid van die huidige aansporingskema is. In hierdie verband moet daar ook bepaal word of dit vir alle vorme van gestremdhede op dieselfde wyse en vir dieselfde tydperk aangebied moet word en of dit nie gedifferensieerd per gestremdheid gedoen behoort te word nie. Navorsing behoort dan uitgebrei te word om in hierdie verband ook na aspekte soos die tydperk van aansporing, die aard van aansporing en die toets van alternatiewe skemas soos byvoorbee1d belastingkorting te kyk .

Tweedens moet die stelsel/skema van aansporing aan die werkgewers bekend gestel word deur middel van 'n aktiewe bemarkingsveldtog. Dit is belangrik dat dit tot op hierdie punt deurgevoer word, want die 'beste stelsel' kan nie werk as die partye wat dit moet aanwend, nie daarvan bewus is nie.

Posontledings behoort gekoördineerd deur werkgewers en ander partye betrokke by gestremdes aangepak te word. Sodoende kan geïdentifiseer word watter poste, mits daar aan kwalifikasievereistes voldoen word, deur gestremdes gevul kan word. 
Kreatiwiteit en visie moet aan die dag gelê word ten opsigte van die identifisering van nuwe/onbekende terreine van werkgeleenthede vir gestremde persone. Werkgewers behoort sensitief te raak om met 'n nuwe visie werkgeleenthede vir gestremdes te identifiseer. 'n Werkgewer wat sensitief is vir die gestremde as werknemer sal moeite doen om wyer te kyk na nuwe/ ander poste wat deur die gestremde gevul kan word. Gevorderde tegnologie skep talle nuwe geleenthede wat deur die werkgewer geïdentifiseer en deur die gestremde benut kan word.

Opleidingsinstansies, nasionale rade en ander kundiges moet egter soortgelyke nuwe visie openbaar. Werkgeleenthede en vaardigheidsrigtings moet ook deur hulle geïdentifiseer word. Die gestremdes moet opgelei word om sodanige poste te beklee en die werkgewer en gestremde werknemer moet bymekaar gebring word. Dit beklemtoon ' $n$ behoefte aan groter koördinasie tussen die betrokke partye.

Met die huidige verskuiwing vanaf die sekondêre (vervaardiging) sektor na die tersiêre (dienste) sektor in die Suid-Afrikaanse ekonomie raak sodanige koördinasie belangriker, veral aangesien navorsing geïnisieer behoort te word om geleenthede, kundigheidstekorte en opleidingsbehoeftes te identifiseer om die gestremde tydig vir toetrede tot die sektor voor te berei.

\section{Summary}

\section{Nature and extent of research}

\section{Problem specification}

The environment (social), training and employers are not necessarily prepared or accessible for the disabled employee, whereas the disabled employee is apparently ready to enter the open labour market. It is thus important to establish through research what the present situation is.

\section{Goals of the article}

This article covers only one facet of the research, namely the perspective of the employer in the open labour market and focuses on the degree of employment, the inclination towards and work achievement of the disabled employee. In addition the reason why certain organizations do not employ disableds will be studied.

\section{Research methodology and extent of research}

A questionnaire was sent to employers in the open labour market who are currently employing, who had previously employed and who has never employed disabled persons.

Of the original 2400 questionnaires posted, a response rate of $35 \%$ was received back. In addition interviews were conducted. The information collected was statistically processed and analysed and a synopsis is represented here.
Conclusions regarding organizations currently employing disabled persons

Analyses indicated that out of a total of 1171081 employees at these organizations, only 3032 are disabled, a mere $0,258 \%$. Looking at these figures, the question regarding compulsory employment of the disabled arises, especially when one looks at the compulsory employment rate of $2 \%$ in the USA and UK and the fact that some disabled persons are requesting $4 \%$ in South Africa.

It was also concluded that employers would rather employ people with physical disabilities than those with functional disabilities such as blindness.

With the placement of appropriate qualified disabled persons, employers must remember the following:

- They must move away from stereotype occupations;

- It is not so much about placing a disabled person, as it is getting the proper qualified person for the vacancy, who might be disabled.

Reasons given by the organizations for employing their disabled employees are that they were suited for the position or were the best applicant $(86,98 \%)$ or for humanitarian reasons $(15,88 \%)$.

$77 \%$ of the organizations have indicated that they will again employ disabled persons, whereas only $23 \%$ responded negative. Not one of the organizations questioned has a policy regarding employment of the disabled.

\section{Organizations not employing disabled persons}

Reasons given for not employing disabled persons are inter alia no applications, type of work not suitable, and legislation. Although the latter doesn't specifically specify that disabled persons can not be employed, employers use it as an excuse for not employing the disabled.

Other excuses given by employers are the following: too many adjustments will have to be made, low productivity, high absence rate, negative acceptance by co-workers. However, when one takes a look at research done by Florian (1978) and Gade \& Toutges (1983), one sees that quite the opposite is true and that the disabled employee's record is just as good or even better than their non-disabled co-workers. A fact confirmed by the research discussed in this article. In spite of these positive conclusions, the opportunities offered to the disabled employee are not the same as for non-disabled employees. They have less or no advancement opportunities and equal salary and other benefits are only available for those disabled persons occupying permanent positions and it is so that it is very difficult to secure the latter.

\section{Recommendations}

There is a need for a national awareness programme of the disabled as employee and the fact that their achievements are the same or even better than that of their co-workers regarding aspects such as productivity 
and absence, must be highlighted. Such an awareness programme must take place on a continuous basis through media coverage and symposia.

Government incentives can play an important role. The current three-year subsidy system can be revised and ascertained whether this system is valid for all types of disabilities for the same period of time. Other forms of incentives for example tax deduction can be considered. Incentives like this must be actively marketed.

The placement of a disabled person is a science. Thorough evaluation of the individual as well as thorough analyses of a position is necessary as a wrong placement can close the door for all those who were to follow. Job analyses must be a co-ordinated process where employers and parties involved with the disabled participate. Employers can identify new areas of job opportunities while the training institutions can prepare the disabled to enter these areas. It is obvious that more co-ordination is necessary especially now with the emphasis moving from the manufacturing sector to the services sector and the disabled must be prepared to enter this sector.

\section{Verwysings}

Departement Nasionale Gesondheid en Bevolkingsontwikkeling. 1986. Verslag van die subkomitee. Opleiding en indiensplasing van die gestremde persone. (Jaar van Gestremde persone) (Voorsitter: S. van Wyk).

Esterhuizen, H.M. \& Van Der Burgh, C. 1982. Die beroepsgesitucerdheid van 'n aantal blinde mans in die RSA. Rehabilitation in South Africa, March, 7-9.

Florian, V. 1978. Employer's opinions of the disabled person as a worker. Rehabilitation counseling bull., vol. 22, 38-34.

Gade, E. \& Toutges, G. 1983. Employer's attitude toward hiring epileptics : implications for job placement. Rehabilitation counseling bull., vol.26, 353-356.

Nesbitt, J.A. \& Hippolitus, P. 1977. Rehabilitating the employer. Parks and Recreation, vol.12, 37,56-57.

Sears, J.H. 1975. The able disabled. J.reabilitation, vol.41, 19-22. 